\title{
Revolutions, Republics and IWMA in the Spanish Empire (around 1873)
}

\author{
Jeanne Moisand
}

In the fall of 1873, Engels published his analysis of "Cantonalist" revolutions which had just burst out in Spain, and were still partially under way. Apart from its role in the ideological struggles of the time, this polemical series of articles (entitled "Bakuninists at work") raised a central question: how was the development of internationalism in Spain linked to different republican revolutionary movements, which broke out across its empire between 1868 and 1878 ? Opened by the liberal revolution of September 1868 , a revolutionary cycle (the "democratic Sexenium") led in 1873 to the unexpected establishment of the First Spanish Republic. According to Engels, a genuine social Republic was now at hand if internationalist workers supported the Government of the "republican socialist" Pi y Margall. Instead, the "false" Spanish International, with its apolitical Bakuninist façade, relied on the so-called intransigent Republicans, "crooks" that led workers in the irresponsible revolutionary creation of small local republics. Beyond the controversy, Engels seemed to share with his opponents the idea that internationalism was irrevocably linked in Spain to a certain type of republicanism. ${ }^{1}$ His attention to the opportunities created by the Spanish revolutionary cycle contrasted with his neglect of the imperial backstage of the Democratic Sexenium. The proclamation of an independent republic in Eastern Cuba in 1869 led Spain to heavy war efforts against the insurgents. Because of this imperial war, coupled with a new Carlist uprising in the peninsula, it was very unlikely that the First Spanish Republic could simply

* This paper has benefited from many advices from Michel Cordillot, and from the readings of Fabrice Bensimon, Quentin Deluermoz, Albert Garcia Balañà and Romy Sanchez, who are warmly thanked here. The research in Havana and in New York has been funded by the GLOBIBER-ANR project directed by Stéphane Michonneau and by the Centre d'histoire du XIXe siècle.

1 Friedrich Engels, "Bakuninist at Work: An Account of the Spanish revolt in the summer of 1873", Der Volkstaat, 31 october, 2 and 5 november 1873, in Engels, Internationales aus dem Volksstaat (1871-1875) (Berlin, 1894); First published in English: K. Marx, F. Engels, Revolution in Spain (Lawrence \& Wishart, 1939). https://www.marxists.org/archive/marx//works/1873/ bakunin/index.htm.

(C) JEANNE MOISAND, 2018 | DOI 10.1163/9789004335462_016 
go through a progressive and peaceful stabilization, as envisaged by Engels. The forgetting of Cuba is interesting because it questioned the very nature of the International Workingmen's Association's (IWMA's) internationalism: by linking their fate to a republic at war against its colony, would Spanish internationalists and their supporters outside Spain show their latent imperialism? However, before addressing this crucial point, let us follow the thread of the questions raised by Engels, about the links between republicanism and internationalism in peninsular Spain during the Cantonalist revolutions.

\section{Cantonal Republics and the Iwma: A Classic Problem}

As was the case of the French "communes" in 1871, adverse narratives to the Cantonalist revolutions immediately saw in these movements the mysterious hand of the International Workingmen's Association. This confusion was used as a pretext for massive arrests of IWMA members after the defeat of the Cantons (between the summer of 1873 and January of 1874): even in Catalonia, where no cantonalist insurrection took place, deportations beheaded the local sections of the IWMA. ${ }^{2}$ Faced with this repression, the Federal Commission of the IWMA in Spain organized subscriptions for imprisoned or exiled internationalists, ${ }^{3}$ while putting the responsibility of the Cantons on the intransigent "bourgeois" Republicans. ${ }^{4}$ Was this assertion justified, or was it essentially aimed at saving the Spanish branch of the IwMA (Federación Regional Española, FRE. See Figure 15.1) from repression? The works of the 1970s and 1980 also argued that the links between the FRE and cantonal revolutions were very weak: not only activists of the IWMA would have remained a minority in most Cantons, but social measures taken by those local republics would have proved extremely feeble. ${ }^{5}$ Cantonalist revolutions would have been republican movements fascinated by Swiss federalism (hence their name) or by regionalism, which had received support from a broad social basis with

2 See below.

3 FRE-AIT, Cartas, comunicaciones y circulares del III Consejo Federal de la Región española, 7 vol. (Barcelona, 1972-87), vol. 6, pp. 186, 289 et 303 .

4 Idem, vol. 5, letter CCLXXIV.

5 José Álvarez Junco, La Ideología política del anarquismo español, 1868-1910 (Madrid, 1976); Clara E. Lida, Anarquismo y revolución en la España del XIX (Madrid, 1972); María-Alice Medioni, El Cantón de Cartagena (Madrid, 1979). On the historiography of cantonalism: M. Gloria Espigado Tocino, "La historiografía del cantonalismo: Pautas metodológicas para un estudio comparado", in Rafael Serrano Garcia (ed), España, 1868-1874: Nuevos enfoques sobre el Sexenio (Junta de Castilla y León, 2002), pp. 111-137. 
cross-class interests. ${ }^{6}$ However, the respect for private property in the Canton of Cartagena reminds the case of the Paris Commune and does not necessarily reveal their "bourgeois" nature. The historiography of the late Franco era also tended to reduce the F RE to its elite. Identifying Spanish internationalism and "Bakuninism", it provided the organization of the IWMA in Spain a material and ideological cohesion which was far from reality: local federations of Barcelona or Valencia proved to be almost as important as the federal commission, and their ideological orientations radically differed. ${ }^{7}$ The gap proved to be deep between Bakuninist leaders and their bases, who believed in the emancipatory power of federal republicanism.

If the republican language appeared in part as a French import, disenchantment with "The Social (Republic)" did not cross the Pyrenees so quickly: on the contrary, the Republic remained very firmly linked with the horizon of emancipation in Spain. ${ }^{8}$ Republicanism was able to overcome the failures of radical liberalism, while resuming its democratic and insurrectionist practices consisting in arming the people and in creating spontaneous municipal juntas and political clubs. The opening of the public space during the Democratic Sexenium accelerated the penetration of republican ideas and deepened the association between radical democracy, Federal Republic and social revolution. The IWMA development in Spain benefited from this radical republican soil, especially after the Commune. The historian López Estudillo demonstrated it in terms of the Andalusian case: by identifying internationalism with democratic and social republic, the communard model exerted a powerful attraction on agricultural laborers and Andalusia city workers. It explains the massive increase in the IWMA membership from the fall of $1871 .{ }^{9}$ In this same period, the most

6 Juan A. Lacomba Abellán, "Reflexiones sobre el Sexenio democrático: revolución, regionalismo y cantonalismo", Anales de Historia Contemporánea, 9 (1993), pp. 19-31.

7 Antonio López Estudillo, Republicanismo y anarquismo en Andalucía, Conflictividad social agraria y crisis finisecular (1868-19oo) (Córdoba, 2001), p. 189; José A. Piqueras Arenas, La Revolución democrática (1868-1874). Cuestión social, colonialismo y grupos de presión (Madrid, 1992) and "Craft works, Industry and Radical Culture in the Age of the First International", in José A. Piqueras, Vicent Sanz Rozalén, A Social History of Spanish Labour. New perspectives on Class, Politics and Gender (New York, 2007), pp. 106-133; Josep Termes, Anarquismo y sindicalismo en España, La Primera Internacional (1864-1881) (Barcelona, [1965] 1977), p. 183.

8 Ángel Duarte, "La Esperanza republicana”, in Rafael Cruz, Manuel Pérez Ledesma (eds.), Cultura y movilización en la España contemporánea (Madrid, 1997), pp. 169-199; Nigel Townson (ed.), El Republicanismo en España (1830-1977) (Madrid, 1994); Miguel González Román, La Pasión revolucionaria: culturas políticas republicanas y movilización popular en la España del siglo XIX (Madrid, 2007). Peyrou Florencia, Tribunos del pueblo: demócratas y republicanos durante el reinado de Isabel II (Madrid, 2008).

9 López Estudillo, Republicanismo y anarquismo, p. 85, p. 82 note 68. 
famous federalists of the 1869 republican insurrections, as Fermin Salvochea, adhered to the FRE, bringing with them many members of the political clubs and workers societies of "intransigent" republicanism. ${ }^{10}$

In the text quoted above, Engels opposed the intransigent "crooks" to $\mathrm{Pi}$ y Margall, who he presented as a "socialist republican." The founder of the Federal Republican Party in 1870, Pi y Margall faced a growing divide within his political family: after the Paris Commune, the right wing of federalism (the benévolos) came closer to the progressive monarchists, while the left side remained "intransigent" and defended both the social republic, the arming of the people and the imperative mandate. During the discussions in the Cortes about the extradition of Communard refugees, Pi y Margall took sides with the intransigents. Against the "individualist" Republicans, he had long advocated state intervention in the economy through agrarian reform. ${ }^{11}$ The defense of $\mathrm{Pi}$ y Margall socialism by Engels is however surprising: a great translator of Proudhon, Pi had long preached the idea of a pact between provinces, municipalities and workers societies to form a republic "from the bottom up".

The divisions between republicans deepened after the proclamation of the Republic on 11 February 1873, following the abdication of Amadeo I. Pi y Margall, Minister and then President of the Republic, sought to broaden the social basis of the regime by negotiating with other political trends within the central institutions of the state. His former supporters accused him of favoring the enemies of the Republic. The "Volunteers of the Republic", intransigent militias which were joined by thousands of citizens, put pressure on the town halls which were still in the hands of monarchists. The IWMA members massively joined these militia ranks: in Valencia, they managed to create their own battalion; in Sevilla, internationalist militia launched an insurgency in June to take the weapons of Maestranza. ${ }^{12}$ The proximity between the FRE and the intransigents also became visible in common candidacies for provincial or municipal deputations, and through secret agreements to organize a future insurrection. ${ }^{13}$ The Spanish Federation of the IWMA, despite its Bakuninist direction, was thus very far from entering in an "apolitical" phase after the Hague Congress. On the contrary, the feverish mobilization of its members to save the

\footnotetext{
10 Gérard Brey, Jacques Maurice, Serge Salaün, Carlos Serrano (eds.), Fermin Salvochea. Un anarquista entre la leyenda y la historia (Cadix, 2009).

11 Charles A.M. Hennessy, The Federal Republic in Spain. Pi y Margall and the Federal Republican Movement, 1868-1874 (Oxford, 1962).

12 López Estudillo, Republicanismo y anarquismo; Piqueras Arenas, La Revolución democrática, p. 645 .

13 López Estudillo, Republicanismo y anarquismo, p. 200 and p. 250.
} 
Republic explains the decrease of internationalist activity after February 1873. However, the field of social struggle was not abandoned: a wave of strikes was launched in May 1873. The last one, which took place in Alcoy (an industrial town near Valencia), resulted in a bloody conflict at the beginnings of July between workers and the mayor. This would be the only insurrection claimed, with that of Sanlucar de Barrameda near Cadiz, by the direction of the FRE after the revolutionary summer of 1873 .

In June, an attempted monarchist coup on the Cortes failed thanks to the intervention of Madrid volunteers, confirming the concerns of the intransigents. Why did Pi y Margall not seize the opportunity to impose a federal and popular constitution? ${ }^{14}$ On the 11th of July, the intransigents in Cartagena rebelled, anticipating a replacement of troops which might have been less favorable to their cause. On 18 July, Pi y Margall resigned, rather than assuming the repression of the insurrection. Other cantons were proclaimed in the following days. Many of them were set up in Andalusia and the Levant, scattered over a wide coastal area from Valencia to Huelva. Cantons were also present - albeit fewer - in Castile. They were proclaimed both in large cities (Cadiz, Seville, Granada, Malaga, Murcia, Cartagena, Valencia, Castellón, Salamanca, Ávila) and in small rural municipalities. The absence of an insurrection in Catalonia deprived the movement of the most decisive area. Catalonia, the first region of the FRE in terms of density of the sections, and the region where federal Republican votes were most numerous, surprised everybody when it supported the central republic. The French section of the FRE in Barcelona (Charles Alerini, Camille Camet, Paul Brousse) unsuccessfully tried to push the local federation into insurgency. ${ }^{15}$ The refusal of the "Spanish Manchester" to proclaim an insurgent Canton has to be linked to the threat of the Carlist insurrection, which was then arriving at the gates of Barcelona. It contributed to the idea that the Cantonalist revolutions did not deserve to enter into the history of the genuine labor movement, and even less so in that of the IWMA.

\section{A Movement of Archaic Workers? The Example of Cartagena Sailors-Soldiers}

The development of the IWMA in Spain was marked by specific features: its chronology, the Bakuninist leanings of the leaders and the sociology of the Spanish workers in the 1870s. Already present in Engels' article, the

\footnotetext{
14 Hennessy, The Federal Republic, Chap. 7.

15 Termes, Anarquismo y sindicalismo en España, p. 213.
} 
backwardness scheme was destined to a great success: the workers of modern industries, isolated in Catalonia, were surrounded by "traditional" workers, who were more likely to be tempted by anti-authoritarian and millenarian discourses, as Hobsbawm would have said..$^{16}$ This dichotomy is reflected in the classification of the different insurrections as whether "social cantons", where the worker element was deemed to dominate, like in Alcoy, and as "political cantons" elsewhere. The canton of Cartagena, the most long-lasting of all (it held the siege by the Central Republic between July 1873 and January 1874), is classified in the latter category. ${ }^{17}$ Yet the city possessed a high, concentrated population of workers related to mining and port activities. A local section of the FRE was founded in 1869: it recruited exclusively from the local military arsenal workers, miners proving unreceptive. Composed of 600 members in 1870, this local section seemed very active, exchanging numerous letters and news with the Federal commission in Madrid during the following year. But the failure of a strike in the arsenal in 1871 led to a rapid decomposition of the section. ${ }^{18}$ According to historian Juan Bautista Vilar, the Internationalists of Cartagena left the field of social struggle and focused on the political activity of intransigent Republicans' clubs, led by notables. The few members of the IWMA who were present in the governing bodies of the Canton, the arsenal worker Pablo Meléndez and the communard refugee Antonio de La Calle, were according to Vilar discarded after a few weeks. The latter proposed social measures which were only partially adopted..$^{19}$

Restricted to the leaders of the Canton, this analysis dismisses the role of the insurgent base, more likely to have been involved into social struggles. The 9,000 to 11,00o fighters of the Canton of Cartagena ${ }^{20}$ undoubtedly had a working-class background: they were insurgent soldiers from the regular army in a context of unequal conscription, and milicians from the popular battalions of the Volunteers of the Republic. The exile of some of the Cantonalists in Oran in January 1874 gives a further indication on the composition of these fighters:

16 Eric Hobsbawm, Les Primitifs de la révolte dans l'Europe moderne, (Paris, Fayard, (1959) 1963).

17 Miklos Molnar, Juan Pekmez, "Anarquismo rural en España y la revolución cantonalista de 1873", in Henry A. Landsberger (ed.), Rebelión campesina y cambio social (Barcelona, 1978), pp. 214-257, p. 254.

18 FRE-AIT, Actas de los Consejos y Comisión Federal de la Región Española (1870-1874), 2 vol. (Barcelona, 1969), vol. 1, p. 61.

19 Juan Bautista Vilar, Los Orígenes del movimiento obrero murciano. La I Internacional, Anales de Historia Contemporánea, 5 (1986), pp. 109-121; Medioni, El Cantón de Cartagena.

20 Antonio Puig Campillo, Historia de la Primera República española. El Cantón murciano, (Cartagena, 1932), pp. 308-309. 
among the 1,636 Cantonalists who fled on the warship Numancia, we count 12 members of the Revolutionary Junta, 10 officers of the army, 248 soldiers, 480 State sailors and 492 convicts (from the prison of Cartagena). ${ }^{21}$

"State sailors", one of the most represented category among these fighters, were actually sea workers requisitioned by the navy. Fishermen, sailors, dock workers, workers associated with the construction of vessels, constituted the special category of "workers of the sea", who escaped conscription in the army (the quintas), but had to register for the navy (the matricula de mar). They were considered as a reserve force and the likeliness of their being called up was much higher for them than for men submitted to the quintas. Subject to a special maritime law, which protected them in the competition with other job categories, ${ }^{22}$ their mobility was extremely controlled, even outside campaigns. ${ }^{23}$ From the outburst of the 1868 revolution, all the Republican revolts were accompanied by the shouts of "Down with the quintas and the matricula de mar! ${ }^{24}$ " The abolitions of these two forms of conscription on 17 February and 22 March 1873 were among the most significant measures of the transition to Republic. The War department replaced quintas by a voluntary enlistment, which was successful only among urban militias. Because of the wars against the Carlist and the Cuban insurgents, it turned out to be impossible to demobilize the troops recruited under the monarchy. On 12 July 1873 , the crew of a dozen warships - the very best of the Spanish fleet - mutinied in Cartagena against a republic that had belied its promise of freedom. Navy crew soldiers revolted against their officers who quickly fled from the Canton: this mutiny of gigantic proportions ${ }^{25}$ made it possible for the Cartagena Canton to last for so long.

The accentuation of military pressure on Spanish workers cannot be understood outside the context of imperial crisis during the Democratic Sexenium. To counter the Cuban separatist insurgency, 180,000 Spanish soldiers were

21 Juan Bautista Vilar, La España del exilio, Las emigraciones políticas españolas en los siglos XIX $y$ XX (Madrid, 2006), p. 274.

22 Jordi Ibarz, Imatges al Moll: els oficis de les feines d'estiba a la Barcelona dels segles XIX $i X X$ (Barcelona, 2008).

23 Enrique García Domingo, El Trabajo en la Marina mercante española en la transición de la vela al vapor (1834-1914), Phd (Barcelona, 2014), pp. 31 and following.

24 Javier de Salas, Historia de la Matrícula de Mar y examen de varios sistemas de reclutamiento marítimo (Madrid, 1879).

25 Pedro María Egea Bruno, "Los Prolegómenos del cantón en Cartagena: El motín de la fragata Almansa”, Anales de Historia Contemporánea, 10 (1994), pp. 409-416; José Luis Pérez Infiesta, "Las Fragatas blindadas españolas y la sublevación cantonal", Revista General de Marina, 248-1 (2005), pp. 69-84. 
recruited and transported to Cuba between 1868 and 1878, a contingent of unprecedented magnitude in a transatlantic war. ${ }^{26}$ Land warfare, organized to fight the guerrilla that throve in Eastern Cuba, accompanied a naval war aimed at defending the coast of "pirate" ships (filibusteros), fueling the insurgency in arms and men from the United States and Latin America. Unable to cope with the transport of troops and with coastal surveillance, the military navy was supported by the Spanish merchant navy, almost exclusively in hand of the Transatlantic Company of Antonio López, Marquis of Comillas. Ennobled for his services, this former slave trader won the monopolies of the mail to the colonies and of the transportation of troops, which earned him considerable profits. ${ }^{27}$ In contact with foreign workers and their ideas, ${ }^{28}$ maritime workers were rendered precarious by the introduction of steam, the concentration of shipping companies and the competition of rail on coastal navigation..$^{29}$ The expansionist Spanish naval policy of the 1850 s and the $186 \mathrm{os}^{30}$ strengthened the military coercion on their mobility. In the military ships travelling to the colonial areas, workers were exposed to the total loss of their political rights. Six peninsular sailors were imprisoned for insubordination in December 1873 in the penal colony of La Havana: they had complained about their poor diets and the state of their ship. ${ }^{31}$ The history of sea workers' politicization, internationalism and revolt must be understood in this imperial context.

\section{Seamen, the Maritime IWMA and the Spanish Colonies}

Despite their absence in the histories of the Spanish labor movement, several signs show the involvement of seamen in the internationalist and federal

26 Manuel Moreno Fraginals, José Moreno Maso, Guerra, Migración y muerte. El Ejército español en Cuba como vía migratoria (Madrid, 1993).

27 María Elena Hernández Sandoica, "La Compañía Trasatlántica española. Una dimensión ultramarina del capitalismo español", Historia contemporánea, 2 (1989), pp. 119-164.

28 British technicians were numerous in the arsenal of Cartagena from the 1850 s. Cristina Roda Alcantud, Historia e ingeniería en el siglo XIX. Vanguardia de la industria naval en el Mediterráneo occidental: el Arsenal de Cartagena (Cartagena, 2008), pp. 324 and following.

29 Jesús María Valdaliso Gago, Los Navieros vascos y la marina mercante en España, 1860-1935: una historia económica, (Bilbao, 1991).

$30 \quad$ Josep M. Fradera, Colonias para después de un imperio (Barcelona, 2005).

31 AHN, Ultr. 4737 , doc. 45 et 46, instancia de D. José Armada y sus cinco compañeros de prisión. 
mobilizations during the years preceding the Canton. ${ }^{32}$ They were well represented in Barcelona during the Spanish first Congress of the IWMA in June 1870: Antoni Marsal Anglora, a mechanic (maquinista) already present at the Congress of Brussels in $1868,{ }^{33}$ represented with the dock worker Ramon Esteve, a society of dock workers which then gathered nearly 600 workers. ${ }^{34}$ Domingo Gras was a steward of the "maritime society of Barcelona": according to his testimony, the sailors were "slaves" all their lives after their inclusion in the "marine grade" during their childhood; they were "exploited" by the captains and were also the "first victims of the State". ${ }^{35}$ One month after the congress, a wave of sea workers strikes occurred in July and August 1870: the workers in the arsenals of Cadiz and Cartagena went on strike first, ${ }^{36}$ followed by the dockers and sailors of Denia near Valencia, ${ }^{37}$ then by the maritime society of Barcelona in August. A new strike broke out in Cartagena in May 1871, which failed. In 1872, a mutiny in another military port, El Ferrol, was a prelude to the Cartagena events of July $1873 \cdot{ }^{38}$ Subjected to combined forms of oppression, sea workers sought their emancipation both from capitalism through the IWMA, and from the imperial state with the insurrectionist republicanism.

Would this struggle lead to the establishment of an anti-imperialistic form of internationalism, circulating overseas? The year before the mutiny of Cartagena, a similar episode had taken place in the Philippines. The revolt of Cavite in 1872 often stands for the first anti-colonial revolt in the history of Philippines, unless this assumption has been criticized. The rebels were mostly recruited in native battalions of soldiers and workers from the local military arsenal. They struggled to keep their tax privileges within the colonial system: while these categories were exempted from the tribute on the natives, a tax reform removed this exemption. Some two hundred rebels took up arms against their peninsular officials, in a revolt of unknown proportions in the colony.

32 Juan Zamora Terrés, Notas para una historia del movimiento obrero en la marina mercante española (Barcelona, 2003).

33 María T. Martínez de Sas, Pelai Pagès (eds.), Diccionari biogràfic del moviment obrer als països catalans (Ed. Universitat Barcelona, 200o), pp. 832-833. Víctor Manuel Arbeloa (ed), I Congreso Obrero Español: Barcelona, 18-26 de Junio de 1870 (Madrid, 1972), pp. 101 y 146-147.

35 Idem, p. 133, "sobre esta clase está pesando una injusticia, de que en nombre de los asociados protesto, y esta injusticia consiste en las matrículas de mar, cuya abolición pido. (...) el capitán (...) nos explota cuanto puede para ahorrar en provecho propio. (...) siendo las primeras víctimas del Estado."

36 Fre-AIT, Actas, vol. 1, pp. 7-8, p. 14, p. 59 et 61 .

37 Piqueras Arenas, La Revolución democrática (1868-1874), pp. 166-167.

38 R. Cartaña, "Pi y Margall y los postulantes políticos", El Cantón federal, 24 nov 1872, pp. 2-4. 
They were finally neutralized and executed on the spot. ${ }^{39}$ None of the sources mentioned any link between the revolt of this colonial arsenal and the FRE, despite the sea workers presence in both. If a form of solidarity eventually appeared, it was caused by the imperial repression, which then multiplied the use of the "filibuster" category and gave it a certain reality by making convicts circulate across the empire. A generation later, the Philippine novelist José Rizal dedicated his book El Filibusterismo (Berlin, 1891) to the revolt of Cavite. Born from the fear of a global dissidence connected by the sea, the repressive imaginary of "filibusterism" was retaken and almost claimed in this novel, erected by Benedict Anderson into a symbol of an alternative internationalism, anticolonialist and anarchist, born in the Spanish end-of-century empire. ${ }^{40}$

No claim of this type appeared in the writings of the FRE in the 1870s. The lack of real solidarity between the revolutionary Peninsula and the insurgents in the Philippines became particularly visible after the failure of cantonal revolutions. The archives of the overseas department record the deportation of 1,076 Cantonalists and former members of the IWMA to Asian penal colonies, and 71 others to Fernando Poo. In the Philippines, peninsular convicts were put at the service of the colonial navy: the "volunteers" could participate in a campaign to subdue the natives of Jolo, Muslim people who resisted colonization. ${ }^{41}$ Even if they were coerced, Spanish cantonalists and Internationalists thus participated in the expansion of the imperial state in Asia. In the Philippines, the absence of a free political space limited the organization of any protest movement, likely to contact - outside the framework of the prison with labor or republican movements in the peninsula. Was it the same in Cuba? One of the earliest of all Latin America labor movements had emerged in the island before the Ten Years Wars (1868-78), promoted by the workers of the tobacco industry. During the war however, political freedom was banned and this labor movement silenced, except during the first months of the 1873 Spanish Republic. ${ }^{42}$ The tobacco worker Saturnino Martínez, founder of the newspaper La Aurora (1866-67), only knew about the existence of the IWMA in 1871 by reading the conservative press after the Commune. Not able to organize a federation in Cuba, he wrote a favorable opinion about the IWMA in an

39 Leandro Tormo Sanz, "La huelga del arsenal de Cavite en 1872", Anuario de Estudios Americanos, 35 (1978), pp. 283-378.

40 Benedict Anderson, Les Bannières de la révolte: anarchisme, littérature et imaginaire anticolonial, la naissance d'une autre mondialisation (Paris, [2005] 2009).

41 AHN, Ultr. 5222, Exp. 2 and Exp. 3, doc. 12.

42 Joan Casanovas, Bread or Bullets! Urban Labor and Spanish Colonialism in Cuba, 1850-1898 (Pittsburgh, 1998). 
article in 1874, which earned him a deportation to Spain. ${ }^{43}$ The attempts of the Spanish Federation of the IWMA to establish contacts with Cuban workers also failed: in 1873, the FRE asked the Federal Council of the IWMA in New York for the addresses of possible international sections of Havana. ${ }^{44}$ Would the United States have represented an Eldorado for Cuban internationalists, and made the link more efficiently in the context of the imperial war between Spain and its colonies?

\section{The Internationalism of the Great Causes and the Cuban Problem}

The works of the 1960s recalled that an internationalism of great common causes had preceded the birth of the IWMA: Polish revolts, Italian unity and the American Civil War had constituted the first passions of the British workers' internationalism. ${ }^{45}$ The Cuban insurrection continued in the vein of the us Civil War and the struggle for the abolition of slavery. Associated with the "universal republic" and the emancipation of America, the Cuban cause attracted many international fighters. North Americans, British, Venezuelans, and Dominicans embarked to help Cuban insurgents in their fight, on ships that came primarily from the United States. ${ }^{46}$ In 1869 , Gustave Cluseret, a future communard and future founder of the first French section of the IWMA in the Us, a veteran of the wars of Italy and of the us Civil War, ${ }^{47}$ contacted the Cuban Junta in New York: he undertook to disseminate information about the Cuban insurrection to all radical European newspapers and maintained that the Cuban question was "that of all peoples ${ }^{48}$ ". A first moment of rupture in this favorable impulse to the Cuban cause occurred on 13 June 1870: President Grant refused to recognize belligerency to independent Cuba, and defined the insurgents as "filibusters ${ }^{49}$ ". The link between the Cuban cause and the "universal republic" became blurred, as the Reconstruction split up in the struggles

43 Joan Casanovas, Bread or Bullets!, p. 96, pp. 110-111.

44 FRE-AIT, Cartas, vol. 5, pp. 98-99.

45 Jacques Rougerie, «Sur l'Histoire de la Première Internationale: Bilan d'un colloque et de quelques récents travaux », Le Mouvement social, 51, (1965), pp. 23-45, p. 29.

46 Gilbert Toste Ballard, Reeve. El Inglesito (La Habana, 1973).

47 Michel Cordillot, Utopistes et Exilés du Nouveau Monde : des Français aux États-Unis, de 1848 à la Commune, (Paris, 2013), pp. 249 and following.

48 La Havane, ANC, Donativos y remisiones, legajo $167, \mathrm{n}^{\circ} 111-129$, lettre du 29 novembre 1869.

49 Ulysses S. Grant, "Special Message" 13June 1870, Online by Gerhard Peters and John T. Woolley, The American Presidency Project. http://www.presidency.ucsb.edu/ws/?pid=70164. 
of the post-Civil war. ${ }^{50}$ The misadventure of the Virginius, an American ship captured in 1873 by the Spanish navy and whose crew was shot, definitely discouraged the last American volunteers to enlist in the Cuban war.

The international labour movement timidly replaced the filibusters of the "universal Republic" in the solidarity with the Cuban cause. In December 1871, an internationalist demonstration gathered around 10,00o persons in New York to honor both the martyrs of the Commune and the victims of the Cuban war. The Spanish internationalist press published the information about this manifestation of a pro-Cuban workers' solidarity. ${ }^{51}$ According to the Spanish Consul in New York, Cuban exiles were having dangerous contacts with refugees from the Commune, and most Cuban workers in Brooklyn and New York had joined the IWma. ${ }^{22}$ These statements seem exaggerated by the anxieties of the diplomat. In April 1872, there was just one Spanish section in the North-American Federation of the IWMA (the 38 th section created in Brooklyn). ${ }^{53}$ It is not clear that it could attract Cubans (being linked as it was with the FRE), and it did not weigh much compared to the many French or German sections. Solidarity still existed with the Cuban cause (as shown by a "message of solidarity" with the Cuban insurgents signed by at least three members of the Society of the refugees from the Commune of New-York in November $1873^{54}$ ) but the link between the General Council of New York and the Spanish federation was undoubtedly much stronger. ${ }^{55}$

The Cuban migrants in the United States were, however, numerous, numbering between 12,000 and 30,000 persons around $1875 .{ }^{56}$ Most of the Cuban

50 Eric Foner, Reconstruction: America's Unfinished Revolution, 1863-1877, (New York, 1988), pp. 494-495.

$51 \quad$ La Federación, Barcelone, 127 (21 enero 1872), p. 2. Michel Cordillot, Utopistes, pp. 270-271.

52 Madrid, RAH, colec. Caballero de Rodas, vol. v. Corr. mando del Gal Conde de Valmaseda, $\mathrm{f}^{\circ} 270-271$, copia de la com. del Cónsul de España en Nueva-York al Ministro plenipotenciario de España en Washington, 28 diciembre 1871-27 enero 1872.

53 Many thanks to Michel Cordillot for this reference. Jacques Freymond, La Première Internationale, Recueil de documents, t. III Les conflits au sein de l'Internationale (Genève, 1971), p. 269 .

54 Dictionnaire biographique du mouvement ouvrier français: le Maitron, CD ROM (Paris, Ed. de l'Atelier-Ed. ouvrières, 1997), Message signé par Ansot fils, vol. 39, EU 1872-1874, note de M. Cordillot; par Edouard Badoureau, et par Jean Lucien Bedouch.

55 The IWma papers, Records of the General Council, 1871-1874, Microfilm by State Historical Society of Wisconsin Records of the Central Committee, 25/04/1873 pp. 23-27, 19/11/1872 pp. 36 et suiv., 11/04/1873 pp. 88-89, 8/08/1873 p. 157. FRE-AIT, Actas, p. 130.

56 Joan Casanovas Codina, "El movimiento obrero cubano durante la Guerra de los Diez años (1868-1878)", Anuario de Estudios Americanos, LV-1 (enero-junio, 1998), pp. 243-266. NYPL, Moses Taylor coll., Box 309, El Pueblo, Nueva York, Julio 27 de 1876, año 1 n.12, p. 2. 
workers were cigar-makers, and they were much more concentrated in Florida, especially in Key West, than in New York, which was the center of the IWMA. ${ }^{57}$ The hundreds of Cuban tobacco workers in New York were not very well received by the combative union linked to the IWMA (CMIU Cigar Maker International Union-1864): the leaders Adolph Strasser and Samuel Gompers accused them of being organized for the independence of Cuba for which they gathered funds in their Sociedad de Artesanos Cubanos (NYC, 1870), rather than for the emancipation of tobacco workers. Their massive migration to the Us after 1868 would have represented a danger for the cause of cigar makers: Gompers would even have been in favor of a blockage of Cuban migration. ${ }^{58} \mathrm{~A}$ further investigation would be necessary to see if this opinion was motivated by a racial prejudice against Cuban workers, many of them being people of color.

In Florida, the mass of Cuban workers was less connected to the IWMA and had to deal with the Southern counter-revolutionary movement: despite the mobilization of free Blacks for racial equality, Democrats regained each State one by one, and imposed their ideal of an unequal and racialized Republic. ${ }^{59}$ In 1876 , when this conquest of the southern States by the Democrats was almost done, the Junta for Cuban independence in the United States began to support them instead of Republicans, as it was used to doing. ${ }^{60}$ La Igualdad (Equality) from Key West published an angry manifesto from the city's radical republican committee: the support of Democrats by the millionaire and leader of the Junta Aldama encouraged "the fatal division of races, giving rise to a very difficult future reconstruction in our Fatherland ${ }^{61}$. As the 1876 electoral campaign revealed, the social gap between the clans of exile overlapped a political and racial opposition between Cubans of southern sensibility, also numerous between poor whites, and those who defended an egalitarian and interracial republicanism, according to the tradition of the Cuban workers movement

57 Evan Matthew Daniel, Rolling for the Revolution: A transnational history of Cuban cigar makers in Havana, Florida and New York City, 1853-1895 (Phd New School University, 2010), p. 6 et p. 121 .

58 Idem, p. 223 et p. 259.

59 Foner, Reconstruction.

60 Gerald Poyo, With All, and for the Good of All: The Emergence of Popular Nationalism in the Cuban Communities of the United States, 1848-1898 (Durham, 1989), pp. 84-86.

61 NYPL, Moses Taylor collection, Box 309, El Tribuno Cubano, Nueva York, 15/og/1876, vol 2, n.13, p. 2. La Igualdad, Cayo Hueso, 16/12/1876, año I n.3, p. 3: "la funesta división de razas, haciendo imposible en el futuro ya no muy lejano la dificilísima reconstrucción de nuestra Patria". 
of the 1860 os $^{62}$ At the same time, in the island, the great Cuban cause associated with universal emancipation was also gradually restricted to a nationalist struggle for a certain type of white hegemony. ${ }^{63}$ This process played a part in the failure of the American Revolution after the Civil War, and in the decomposition of workers' internationalism when it crossed the Atlantic.

\section{Conclusion}

In the 1860 s, the revolutionary Atlantic, with its abolitionist and radical republicanism, fed the "imagined community" of European workers. Its role was completely reversed in the 1870s, as the history of the IWMA in Spain reveals. Spanish internationalism borrowed its language from various socialisms, from abolitionism and from radical and federal republicanism. Armed insurrectionism was also fundamental, and was aimed at stopping the counterrevolutionary dynamic which emerged early after the Gloriosa revolution (September 1868), and which disposed of an essential base in the pro-slave Spanish Cuba. ${ }^{64}$ The Cuban exile community in the United States, which was first involved in the cause for universal emancipation, then abounded in the direction of the white Cuban nationalist reaction. As a last attempt to reverse this trend, the Cantonalist revolutions of the summer of 1873 happened too late in the story of the IWMA, after the splits of The Hague: they were seen as a demonstration of what the "Bakuninists at work" were worth and did not receive any support from the IWMA. However, the insurrection of the sailors of Cartagena, the most powerful of all these local revolutions, reflected the effort of organized and "internationalized" workers to resist the pressure of the imperial war and of the counter-revolution prevailing in the Spanish Atlantic.

62 Onoria Céspedes Argote (ed), Diario y correspondencia de Francisco Vicente Aguilera en la Emigración (Estados Unidos (1872), (La Habana, 2009), tomo II pp. IX-XII; Casanovas Codina, "El movimiento obrero cubano durante la Guerra de los Diez años (1868-1878)".

63 Ada Ferrer, Insurgent Cuba: Race, Nation, and Revolution, 1868-1898 (Chapel Hill, 1999).

64 Piqueras Arenas, La Revolución democrática. 


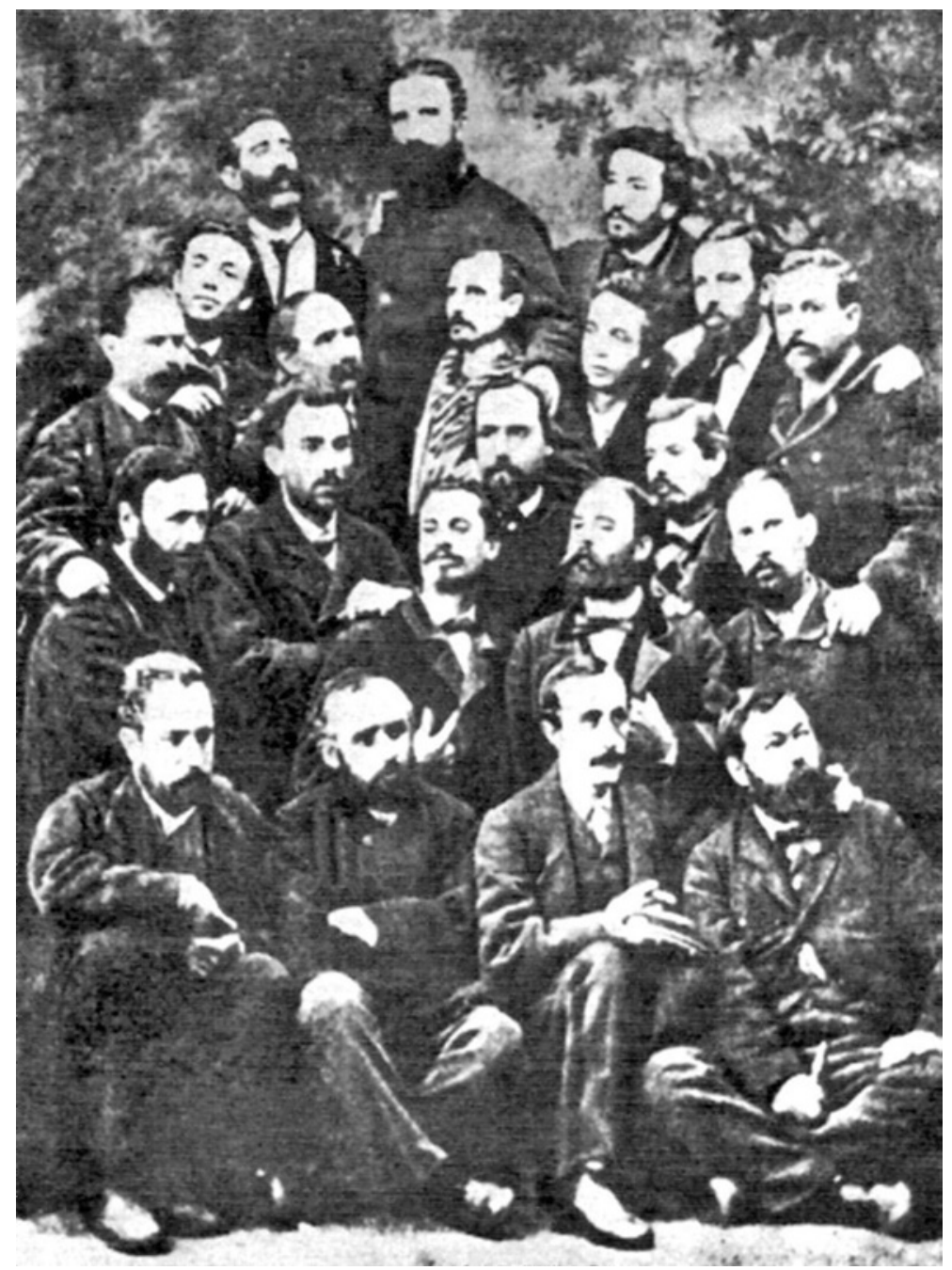

FIGURE 15.1 The founders of the Spanish Regional Federation.

Photograph of the Founders of the Spanish Regional Federation of the IWMA in Madrid, around 1868-69.

From the top and from left to right: Giuseppe Fanelli, Angel Cenagorta, José Rubau Donadeu, Manuel Cano, Francisco Mora, Marcelino López, Antonio Cerrudo, Enrique Borrel, Anselmo Lorenzo, Nicolás Rodríguez, José Posyol, Julio Rubau Donadeu, José Fernández, José Adsuara, Quintín Rodríguez, Miguel Langara, Antonio Gimeno, Enrique Simancas, Angel Mora, José Fernández, Benito Rodríguez.

Anselmo Lorenzo, El Proletariado Militante. Memorias de un internacional, Madrid, Confederación sindical solidaridad obrera, 2005, front Page and pp. 49-50. 